\title{
FIRST BREEDING RECORD OF THE NORTHERN WHEATEAR IN MANITOBA
}

KEVIN C. HANNAH and THERESA A. HANNAH, Canadian Wildlife Service, \#200, 499998 Avenue NW, Edmonton, AB T6B 2X3. E-mail: kevin.hannah@ec.gc.ca.

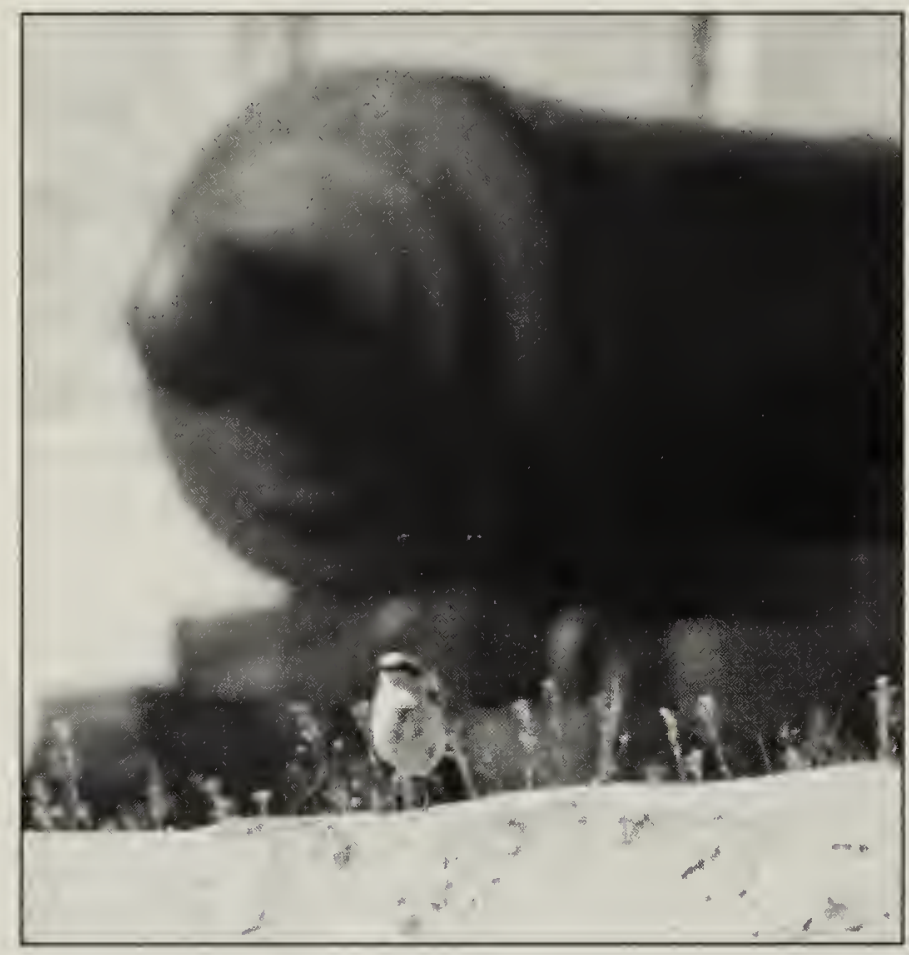

Figure 1 - Male Northern Wheatear at Fort Prince of Wales, Churchill, MB, July 7, 2006.

Theresa Hannah

The Northern Wheatear is one of approximately 20 species in a relatively small group of thrush-like passerines in the genus Oenanthe. Of this primarily Palearctic genus, the Northern Wheatear has the widest global distribution, with two distinct, subspecific breeding populations occurring in North America. The western or nominate race $(O$. 0 . oenanthe) occurs in Alaska, Yukon and the northwestern Mackenzie district of the Northwest Territories; the eastern or Greenland race (O. o. leucorhoa) occurs in northeastern Canada, Greenland and Iceland. ${ }^{5}$

The main stronghold of the Greenland race in Canada includes Ellesmere and Baffin Islands, and the Atlantic coast of Labrador, with smaller, isolated breeding populations on Cornwallis

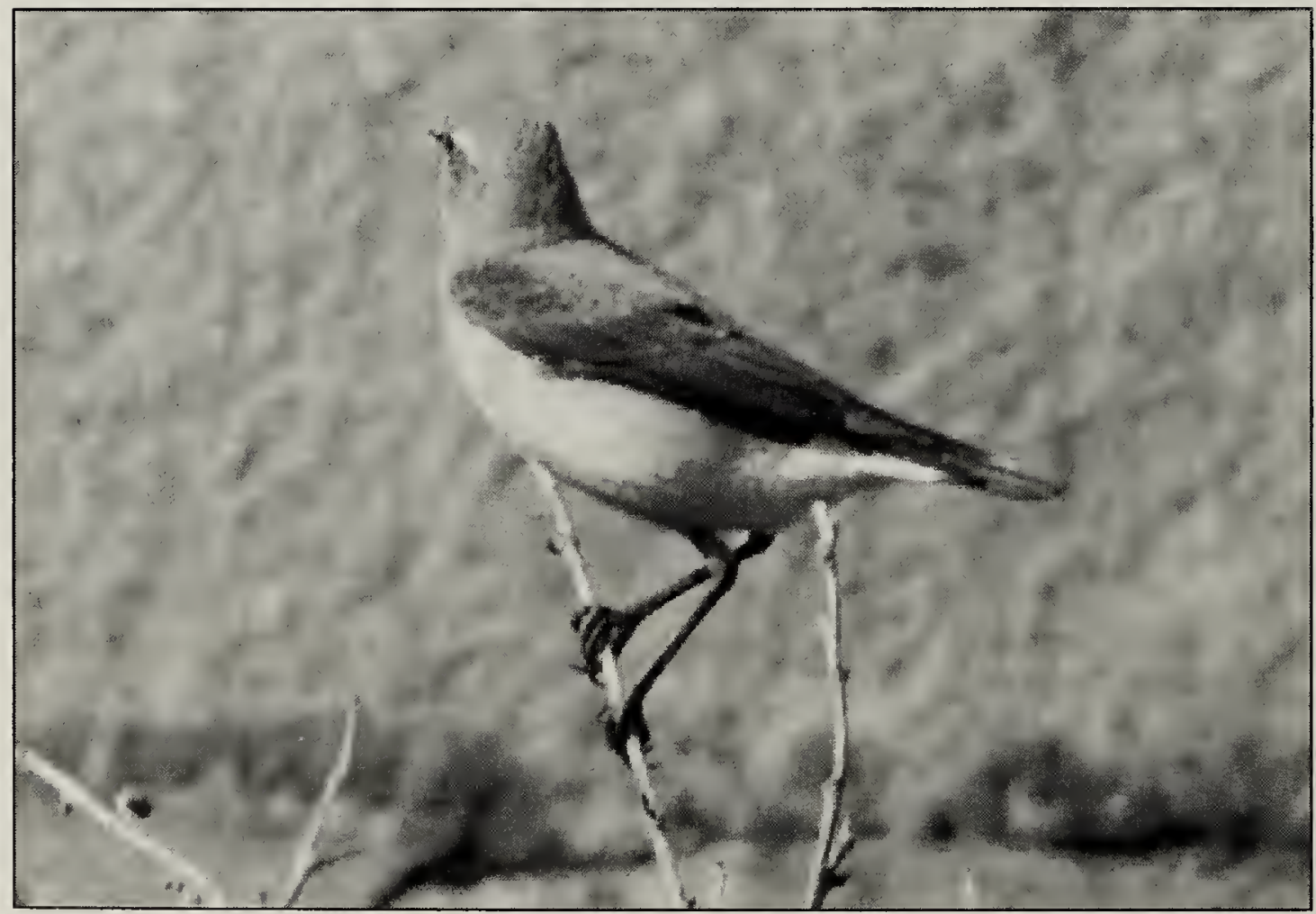

Figure 2 - Female Northern Wheatear perched outside nest at Fort Prince of Wales, Churchill, MB, July 7, 2006. and Coats Islands, and the northern tip of Ungava Peninsula. ${ }^{3}$ In recent years, i sol a te d breeding records have come from Rankin Inlet, on the west shore of Hudson's $\mathrm{Bay}^{6}$, along with Inukjuak, Akuliuik, and 
Aupaiuk, all on Ungava Peninsula, suggesting that this subspecies is expanding its range west and south around Hudson's Bay. ${ }^{4}$ In Manitoba, there are no confirmed breeding records for this species, though several spring and early fall sightings have occurred at Churchill. ${ }^{4}$ We present here the first published record of the Northern Wheatear breeding in Churchill, Manitoba, well south of the previous southern breeding limit for this species in Canada.

On a visit to Prince of Wales Fort National Historic Site $\left(58^{\circ} 47^{\prime} 55^{\prime \prime} \mathrm{N}\right.$ $\left.94^{\circ} 12^{\prime} 45^{\prime \prime} \mathrm{W}\right)$, located northwest of the town of Churchill, MB (58 43' $30^{\prime \prime} \mathrm{N}$ $94^{\circ} 07^{\prime} 00^{\prime \prime} \mathrm{W}$ ), on 7 July 2006 , we observed a male Northern Wheatear with insects in its bill, perched on one of the stone walls within the fort (Figure 1). There were approximately 30 visitors at the fort and the bird appeared to be quite agitated, moving constantly from wall to wall within the fort courtyard. A female Northern Wheatear, also with insects in its bill, perched in a small bush approximately $1 \mathrm{~m}$ from the north, inner courtyard wall of the fort (Figure
2 ), eventually flying into a small $30 \times 15$ $\mathrm{cm}$ triangular opening in the stone wall (Figure 3). We immediately heard the sound of nestlings in the opening and within a few seconds the female reappeared, carrying a fecal sac in its bill. Over the span of approximately 20 minutes, we observed both adults each make two feeding visits to the nest. The opening in the stone wall was approximately $15 \mathrm{~cm}$ deep, with a deeper cavity off to the right side, extending another $15 \mathrm{~cm}$. The nest was located at the end of this L-shaped cavity. It was not possible to see the nest, so we were unable to count the number of nestlings present. Given the frequency of vocalizations when the adults entered the nest, we conservatively estimated that there were at least two nestlings inside.

To reconstruct the breeding chronology of this nesting pair, we compiled the 2006 observations of Northern Wheatears near Churchill, MB (Table 1). On 31 May, a single adult male Northern Wheatear was observed just east of the town of Churchill, near Bird Cove (E. Nol, pers. comm.). We

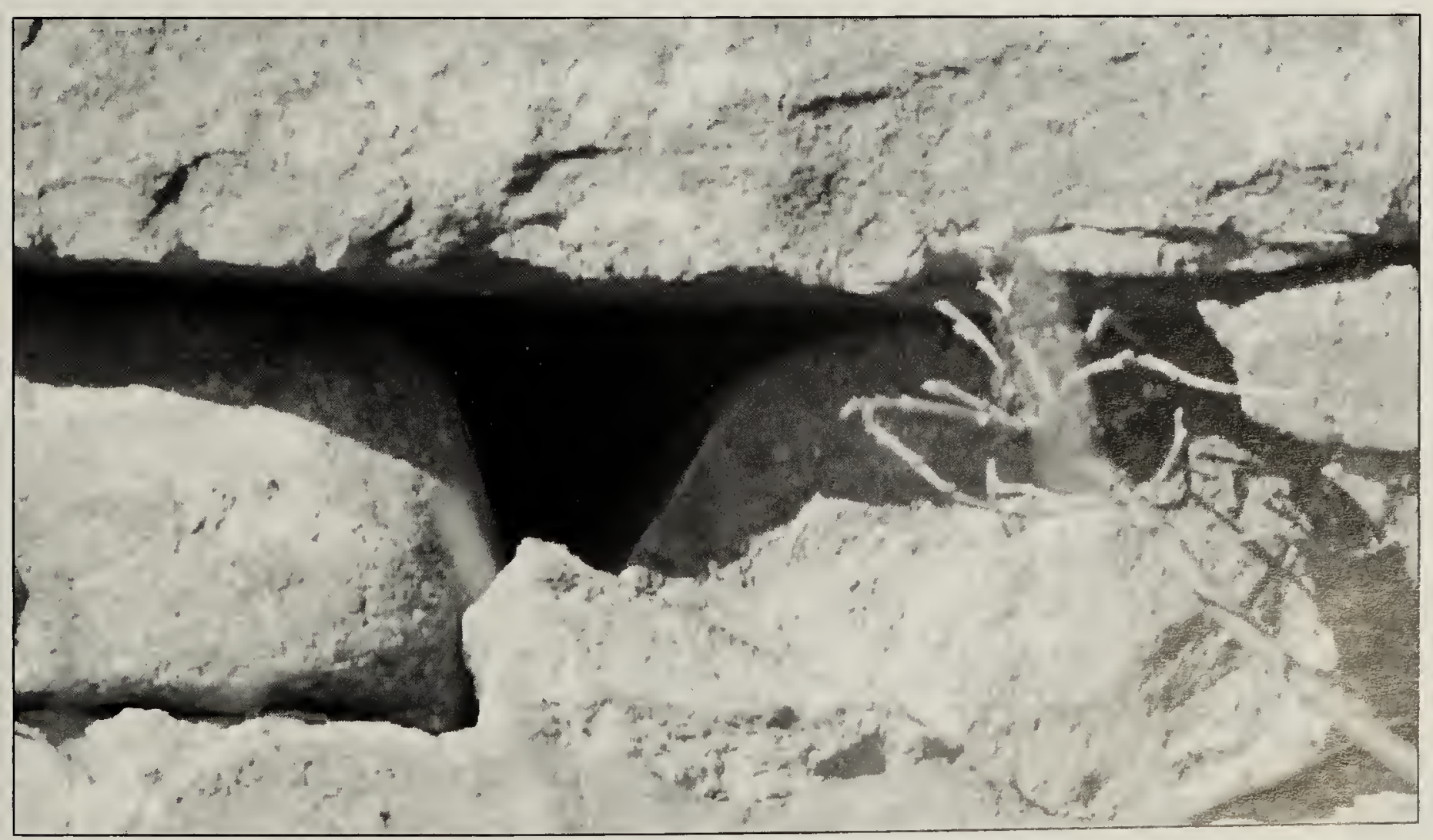

Figure 3 - Northern Wheatear nest cavity at Fort Prince of Wales, Churchill, MB, July 7,2006

Kevin Hannah 
later learned that Allen and Della Wells had observed a pair of wheatears at the Prince of Wales Fort on 29 June (pers. comm. from Bonnie Chartier to Rudolf Koes), and Parks Canada staff observed adults carrying food to a possible nest cavity on 5 July (Cam Elliott, Parks Canada, pers. comm.), several days prior to our observation. By backdating these observations with published accounts of this species' breeding ecology, we estimate the dates for the chronology of this nest shown in Table 1.

Our estimated breeding chronology, while conservative, does show an early
June arrival on the breeding grounds at Churchill as suggested for $O$. $O$. leucorhoa in eastern Canada ${ }^{4}$, though estimated egg laying, hatching and fledging dates are slightly later for this nest than accounts from nests in Rankin Inlet ${ }^{6}$ and Baffin Island. ${ }^{8}$ Despite subsequent visits to the area on 11 and 17 July (Cam Elliott, pers. comm.; Rudolf Koes, pers. comm., respectively), neither the adults nor any fledglings were observed, so it is unclear whether this nest was successful. Given that the young can disperse up to $70 \mathrm{~m}$ within the first 24 hours after fledging ${ }^{1}$, it is possible that the birds had dispersed far enough

\begin{tabular}{|c|c|c|}
\hline Date & Event & Rationale \\
\hline $\begin{array}{l}11-J u l-06 \& \\
17-J u l-06\end{array}$ & $\begin{array}{l}\text { observations by Parks Canada staff failed } \\
\text { to locate adults or fledglings }\end{array}$ & \\
\hline 7-Jul-06 & $\begin{array}{l}\text { observation of nest with } \geq 2 \text { nestlings } \\
\text { estimated to be at least } 8 \text { days old* }\end{array}$ & $\begin{array}{l}\text { *Assume hatch date on or before } \\
29 \text { June, as adults carrying food }\end{array}$ \\
\hline 5-Jul-06 & $\begin{array}{l}\text { observation of adults carrying food (Cam } \\
\text { Elliott, Parks Canada) }\end{array}$ & \\
\hline 29-Jun-06 & $\begin{array}{l}\text { observation of adults carrying food by } \\
\text { Allen and Della Wells (pers. comm. from } \\
\text { Bonnie Chartier to Rudolf Koes) }\end{array}$ & 12-14 day incubation period ${ }^{1}$ \\
\hline 17-Jun-06 & estimated date last egg laid & one egg laid every $24 \mathrm{~h}^{1}$ \\
\hline 15-Jun-06 & estimated first egg laid (2 egg clutch) & $\begin{array}{l}\text { egg-laying commences } 3 \text { days } \\
\text { after nest is constructed }\end{array}$ \\
\hline 12-Jun-06 & estimated completion of nest construetion & 2-7 day nest construction period ${ }^{7}$ \\
\hline $10-J u n-06$ & estimated initiation of nest construction & female arrival 7 days after male ${ }^{1}$ \\
\hline 3-Jun-06 & estimated male arrival at breeding site & \\
\hline 31-May-06 & $\begin{array}{l}\text { observation by Erica Nol of male at Bird } \\
\text { Cove near Churchill, MB }\end{array}$ & \\
\hline
\end{tabular}

Table 1 - Summary of estimated breeding chronology, with significant events and rationale for how dates were calculated. 
away from the nest site that they may have gone unnoticed by observers on subsequent visits.

The western and southern range expansion of the Greenland race of Northern Wheatear in eastern Canada has been documented over many decades, though the underlying mechanism responsible for the expansion is still unknown. Recent climate warming, especially in arctic regions, may partially explain this observed range expansion. The western and southern coasts of Hudson's Bay are the last to become ice free in spring and are some of the earliest areas to freeze again in the fall. ${ }^{2}$ Based on patterns of sea ice, the western and southern coasts of Hudson's Bay have been experiencing significantly earlier spring breakup and later fall freeze-up in recent decades. ${ }^{2}$ This pattern of spring break-up and fall freeze-up does coincide with the recent range expansion in western and southern Hudson's Bay by the Greenland race of the Northern Wheatear, suggesting that the climate around Churchill, MB, has moderated enough in recent decades to permit successful breeding by this species. The slightly later breeding chronology of this nest versus nests in more northern portions of the breeding range, which have longer ice-free periods, may also support this suggestion.

The Greenland race of Northern Wheatear winters primarily in tropical Africa $^{5}$, and recent evidence suggests that, in fall, migrating birds may accomplish the transatlantic crossing from the east coast of Canada to the west coast of Africa in one direct flight of more than $4000 \mathrm{~km}^{9}$. The additional distance that birds breeding in western or southern Hudson's Bay would need to travel to reach the northern limit of their wintering grounds, makes this one of the greatest migrations known in passerine birds (in excess of 8800 $\mathrm{km}$ ). Given the rapid rate of climate change in arctic regions, the Northern Wheatear may establish a completely circumboreal breeding distribution ${ }^{8}$, making it important for observers to continue monitoring the potential range expansion into portions of northeastern Manitoba and northwestern Ontario, along with portions of the central Canadian arctic.

\section{Acknowledgements}

The authors would like to thank Cam Elliott, Rudolf Koes, and Erica Nol for access to unpublished observations. We also appreciate comments by the editor and an anonymous reviewer on an earlier version of this manuscript.

1. CONDER, P. 1989. The Wheatear. Christopher Helm, London, UK.

2. GAGNON, A. S., and W. A. GOUGH. 2005. Trends in the dates of ice freeze-up and breakup over Hudson Bay, Canada. Arctic 58(4):370(13).

3. GODFREY, W. E.1986. The Birds of Canada Revised Edition. National Museum of Natural Sciences, Ottawa, ON.

4. KOES, R. F.1995. The northern wheatear in Canada. Birder's Journal 4(1): 21-28.

5. KREN, J., and A. C. ZOERB. 1997. Northern Wheatear (Oenanthe oenanthe). In The Birds of North America, No. 316 (A. Poole and F. Gill, eds.). The Academy of Natural Sciences, Philadelphia, PA, and The American Ornithologists' Union, Washington, D.C.

6. LEIN, M. R., and W. J. MAHER.1970. First nesting of the Wheatear in western Hudson Bay, Canada. Auk 87: 171-172.

7. MORENO, J. 1989. The breeding biology of the wheatear Oenanthe oenanthe in south Sweden during three contrasting years. Journal für Ornithologie 130(3): 321-334.

8. SUTTON, G. M. and D. F. PARMELEE. 1954. Nesting of the Greenland Wheatear on Baffin Island. Condor 56: 295-306.

9. THORUP, K., T. E. ORTVAD, and J. RABØL. 2006. Do nearctic northern wheatears (Oenanthe oenanthe leucorhoa) migrate non-stop to Africa? Condor 108:446-451. 